\title{
Academic Freedom: In Justification of a Universal Ideal
}

\section{Terence Karran}

Centre for Educational Research and Development, University of Lincoln, LN6 7TS UK. Email: tkarran@lincoln.ac.uk

[This is an electronic version of an article published in the journal Studies in Higher Education 'Academic Freedom: In Defence of a Universal Ideal' Studies in Higher Education, Vol. 34, No. 2. Studies in Higher Education is available online at: http://www.informaworld.com]

BIOGRAPHICAL NOTE: Dr Terence Karran works in Centre for Educational Research and Development, at the University of Lincoln, in the U.K. He is also a Docent Professor in the Faculty of Education at the University of Oulu in Finland. From 2005 to 2007, he was a Visiting Professor at the Universidad Autónoma de Guadalajara in México, and Director of the Distance Learning Centre and the Mexican National Co-Ordination Centre for the World Bank Institute's Global Development Learning Network for Latin America and the Caribbean. 


\section{Academic Freedom: In Justification of a Universal Ideal}

ABSTRACT: This paper examines the justification for, and benefits of, academic freedom to academics, students, universities and the world at large. The paper surveys the development of the concept of academic freedom within Europe, more especially the impact of the reforms at the University of Berlin instigated by Wilhelm von Humboldt. Following from this, the paper examines the reasons why the various facets of academic freedom are important and why the principle should continue to be supported.

Keywords: academic freedom; European Union; von Humboldt.

\section{Introduction and Rationale}

This paper's purpose is to critically examine the justification for, and benefits of, academic freedom to academic staff, university students, and society in general. The paper's rationale is as follows. Firstly, to increase awareness of academic freedom, among the academic community and society at large. Hamilton (1996, 550) asks: 'Why is there so little collegial public defense of freedom of academic thought?' The answer may lie in the fact that '[w]hile academics pay lip service to academic freedom, all too few have given the concept much thought. Many of us have a muddled and inchoate idea of what it means' (Hillier 1989, 117), such that 'academic freedom continues to be a commonly used but misunderstood concept. ... only a minority of academics bother to explain what the concept of academic freedom means to them or even know what the concept really is' (Moens 1991, 58). However, Weidner (2001, 265) rightly states that '[a] part of the academic freedom we owe to new faculty is clarity and honesty about the parameters within which it operates'. Hence, Rabban exhorts that 'the academy should confront more closely its own understanding of this vital concept' (Rabban 1987, 1429f) because by raising awareness of academic freedom, those within the academy will be better able and motivated to defend it. Thus '[w]e need a strong, self confident, independent faculty to protect the core concept of academic freedom' (Haddon 1987, 1562), because, as Dodds points out, '[t]he academic fraternity has not been too successful in explaining to laymen what this unique thing, academic freedom, is and why it is indispensable' (Dodds 1963, 603), in fact McGuinness believes that 'university lecturers and researchers . . . have generally done a bad job of explaining to the public why it is in the public interest to protect it' (McGuinness 2002, 1). This deficiency is part of a general failing identified by Metzger, (1987, 1290) who observes that 'a discomforting perception of the weak theoretical underpinnings of this concept seems to go with an inclination to write about it at all'.

Additionally, previous studies of academic freedom have been subject to criticism. For example, Barnett argues that '[t]he traditional discussions of academic freedom, whatever their superficial differences, are also depressingly uniform. They frequently exhibit the following characteristics: a lack of specificity; a concern for the academic freedom of staff not students; a 
defensive proclamation of the rights of academics; and a disinclination to say anything about the duties that should accompany academics' rights’ (Barnett 1990, 137). Similarly Gerber observes that '[t]oo often, ... references to academic freedom in public discourse are formulaic or disingenuous and fail to take in to account the full meaning of the concept' (Gerber 2001, 23). For example, Moody's (1996) justification of the different claims of academic freedom, undertaken a decade ago, provides a useful discussion of the consequentialist and intrinsic justifications for scholarly freedom, but ignores Lernfreiheit (the freedom of students to study where they chose), which many commentators regard as a central pillar of the concept. More trenchantly, Standler states that ' $[\mathrm{t}]$ here is a large literature on academic freedom, mostly written by professors, and mostly consisting of self-serving praise and unsupported assertions' (Standler, 2000). Hence a second rationale is to address the shortcomings of previous analyses, by providing specific concrete evidence of the value of the elements of academic freedom, to academics, to students, universities and the world at large.

The theoretical and functional foundations of the concept originated within the nations of Europe, which was the cradle of the modern idea of academic freedom within a research university. Academic freedom, conceived of as a particular liberty given uniquely to university scholars, arose from, and contributed to, the development of the university in Europe during the $11^{\text {th }}$ and $12^{\text {th }}$ Centuries. It remains an important defining characteristic of the workings of Universities in the European Union. For example, the Magna Charta Universitatum (EUA 1988, 1) instituted by the European Universities Association, states that: 'Freedom in research and training is the fundamental principle of university life, and governments and universities, each as far as in them lies, must ensure respect for this fundamental requirement'. Similarly the European Union Revision Treaty states in Article II-73 that ' $[\mathrm{t}]$ he arts and scientific research shall be free of constraint. Academic freedom shall be respected' (E.U. 2007, 12). Like the EU Constitution which it replaced, the new Treaty protects rights, yet imposes burdens, and is unlikely to receive electoral ratification unless voters across the EU states believe that the benefits of its constituent elements outweigh the costs. Society at large will only sanction the granting of a particular freedom (like academic freedom), to a specific group comprising academic scholars and their students, and to which all others are denied, if it is persuaded that these freedoms produce net benefits. Hence a third rationale is to present a coherent argument to the general public as to why it should continue to support protection for academic freedom in national legislation and supra-national treaties.

Academic freedom is part of a wider set of complementary human rights, with an evident link between academic freedom and freedom of speech - as Connolly $(2000,71)$ observes 'academic freedom is a kind of cousin of freedom of speech'. Indeed Preece illustrates the close links between the two. First, as all academic activity in the pursuit of knowledge involves dissemination and 
public debate 'restriction of freedom of speech automatically involves a restriction of academic freedom, except where academics are given some special freedom of speech, not available to members of society in general'. Conversely, as academics are involved in the process of public debate 'any restriction of academic freedom necessarily involves a major direct impact upon freedom of debate'. Additionally, as academics create new knowledge by challenging orthodoxy and the status quo, 'they are particularly vulnerable to any lack of freedom of speech in a society, because existing entrenched interests will ... resist the challenge posed by new ideas'. Finally, '[w]hen a society is in the process of becoming more authoritarian, both academic freedom and freedom of speech will come under attack because of the linkages’ (Preece 1991, 32f).

Consequently, academic freedom is recognised by international bodies like UNESCO as a touchstone and guarantor of other fundamental human rights, such as freedom of speech. In the past struggles for freedom of speech, university academics were often prominent, not least because their specialist knowledge enabled them to mount valid attacks on dictatorial governments, monarchies and the church. For example, in 1633 the Pope imprisoned Galileo for expressing the belief that the earth moved around the sun. Such persecution of academics continues - in 2000 a Sociology Professor in Egypt was unlawfully imprisoned for helping to make a documentary film about election irregularities. Hence, in addition to being important to universities and their academics, academic freedom is an indicative facet of freedom within wider society, such that where academic freedom is limited, other freedoms, like freedom of speech and expression, are likely to be in jeopardy. Thus by preserving academic freedom, other fundamental freedoms are also made safe. As Polanyi $(1947,3)$ noted: 'The analysis of the grounds on which freedom rests is of great practical interest to those who love freedom. For by clarifying these grounds we hope to make them more secure'. Hence the final rationale is that strong arguments for academic freedom are also strong arguments for the preservation of other basic human rights.

\section{The Development of Academic Freedom}

The lineage of academic freedom is as long and complex as those of the universities which have invoked it. Thorens notes that ' $[\mathrm{t}]$ he historical origin of university autonomy and academic freedom goes back to the High Middle Ages in Europe' (Thorens 2006, 92), while according to Metzger (1973, 94), it ca be traced back to 1158, when the Holy Roman Emperor Frederick Barbarossa issued the Authentica Habita edict protecting scholars. As Lenhardt (2002, 277) notes '[a]cademic freedom had started in the medieval university as a feudal privilege of the professors to authoritatively teach and interpret the scholastic doctrines'. Subsequently, as Neave (1988) relates, two basic prototypes emerged, in Bologna and Paris. In Bologna, autonomy was vested in the student universitas: professors were hired by the students, who also elected the Rector. In the 
examination of candidates for degrees, the authority of the masters was paramount, but in all other matters the students reigned supreme. By contrast, in Paris autonomy was considered in terms of the freedom to teach and applied to the professors rather than the students.

Both these institutions were subjected to external attempts at control, and responded similarly by migrating to other towns - Vincenza, Arezzo, Padua and Sienna in the case of Bologna and, as Súilleabháin relates, 'in 1217 they basically held the town of Bologna to ransom by withdrawing from the town for three years until such time as their various demands for greater control over the studium and the life of the town itself were met' (Súilleabháin 2004, 18). Similarly, as Traver reports, actions like the Great Dispersion of 1229, which caused a migration of staff and students from Paris to Angers, Orleans and Oxford, lead to scholarly liberty being 'acknowledged as a university right ... in 1231, in Pope Gregory IX's famous bull, the so-called magna carta of the University of Paris, Parens Scientiarum' (Traver 1997, 16). In turn, following feuds between gown, town, and crown, the Paris model reached Cambridge and eventually the United States, with the creation of colleges such as Harvard, Yale, Princeton and others.

Stewart $(1991,1)$ has documented 'the first clear articulation of issues of academic freedom in the English-speaking world' when disaffected staff of Glasgow University tried to break the Principal's hold on university affairs by getting the student body to elect a rival candidate for Rector in 1716-17. However, as Goldstein rightly points out, 'the modern development of the doctrine of academic freedom is largely derived from the nineteenth century German concepts of Lehrfreiheit and Lernfreiheit' (Goldstein 1976, 1293) which are associated with the reforms instituted at the University of Berlin by Wilhelm von Humboldt. The analysis by Paletschek (2001) challenges the centrality of Humboldt's contribution which, she argues, is at variance with historical fact. For example the 1809-10 memorandum in which Humboldt's university plan is detailed (Über die innere und äussere Organisation der höheren wissenschaftlichen Anstalten in Berlin), was not published until the turn of the century, following its discovery by the historian Bruno Gebhardt, while researching a biography of Humboldt, after which it was discussed widely in Berlin University during the years preceding the university's centennial celebrations in 1910. Similarly, Nybom (2003, 144) agrees that the '[t]he intellectual core and institutional rationale of the Humboldtian university concept rested on ... ideological building blocks which were ...integral dimensions of German idealistic philosophy, and, consequently, not Wilhelm von Humboldt's own original intellectual inventions'. The 100th anniversary celebrations of the founding of Berlin University in 1910 played a crucial role in the formation of the so-called 'Humboldtian idea of a university', as well as 'the Humboldt model'. Consequently, Miyasaka $(2005,7)$ opines that “"the traditional creation of Berlin University” was consciously carried out at that time'. 
Hence, it was not until the 20th century that the 'Humboldtian idea of a university' became widely known and adopted, in Germany and elsewhere in Europe. Moreover, as Anderson (2000, 12) has noted, 'what happened at the end of the nineteenth century was not so much the triumph of the Humboldtian ideal as a new synthesis in which elements of both Enlightenment and Humboldtian traditions were merged'. However, it is difficult to demur with Howard's observation that '[g]ranting the complex antecedents behind all historical beginnings, few would nevertheless gainsay that it was most notably in post-revolutionary Prussia, beginning with the dramatic founding of the University of Berlin in 1810, that the modern university first appeared on the historical stage' (Howard 2006, 4). Similarly, Jones argues that 'this was the idea of the university which, more than any other, transformed the functioning of learning and higher education in nineteenth-century Europe' (Jones 2007, 5). This new idea of the university quickly extended its influence beyond Europe to the USA. For example, the theologian Philip Schaff, a Privatdozent in the University of Berlin in 1842 and later a Professor in New York, remarked that '[t]he university of Berlin, although one of the youngest, occupies the first rank of all similar institutions in Germany not only, but in the world'(Schaff 1857, 63). Abraham Flexner, the American educator and cofounder of Princeton's Institute for Advanced Study, was similarly convinced of the excellence of German universities following Humboldt's research and reported that 'Humboldt conceived the salvation of the German nation as coming from the combination of teaching and research, and time has proved him right', leading Flexner to opine that 'a university in this sense we did not possess until the Johns Hopkins University modestly opened its portals in 1876' (Flexner 1930, 312, 42). The pre-eminence of Humboldt's model in the USA has lead Bruch $(1997,27)$ to conclude that 'the idea of the modern university according to the conceptions of Schleiermacher and Humboldt may today be better preserved in the North American than in the German system of higher education'.

Within German universities built on Humboldtian principles 'academic freedom embraced three interrelated principles: Lehrfreiheit, Lernfreiheit and Freiheit der Wissenschaft' (Metzger 1987, 1269). As Hofstadter and Metzger relate: 'By Lehrfreiheit, the German educator meant two things. He meant that the university professor was free to examine bodies of evidence and to report his findings in lecture or published form -- that he enjoyed freedom of teaching and freedom of inquiry. . . . This freedom was not, as the Germans conceived it, an inalienable endowment of all men, ... rather, it was the distinctive prerogative of the academic profession, and the essential condition of all universities. In addition, Lehrfreiheit ... also denoted the paucity of administrative rules within the teaching situation: the absence of a prescribed syllabus, the freedom from tutorial duties, the opportunity to lecture on any subject according to the teacher's interest. Thus, academic freedom, ... was not simply the right of professors to speak without fear or favor, but the atmosphere of consent that surrounded the whole process of research and instruction' (Hofstadter and Metzger 
1955, 386f). Hence Lehrfreiheit referred to 'the statutory right of full and associate professors, who were salaried civil servants, to discharge their professional duties outside the chain of command that encompassed other government officials. It allowed them to decide on the content of their lectures and to publish the findings of their research without seeking prior ministerial or ecclesiastical approval or fearing state or church reproof' (Metzger 1987, 1269). Hence, focusing on the rights of the academic staff, this aspect of the Humboldtian model of academic freedom had precedents in the University of Paris model.

The second aspect, of Lernfreiheit, refers to 'learning freedom’ but as Metzger relates, within the national context of Germany at that time, this right amounted to 'a disclaimer by the university of any control over the students' course of study save that which they needed to prepare them for state professional examinations or to qualify them for an academic teaching license. It also absolved the university of any responsibility for students' private conduct, ... (hence) ... the German university confronted its student body primarily as a purveyor of knowledge and as a credentializing agency, not as a parent surrogate or landlord. For their part, German students, obliged to find their own lodgings and diversions, liberated from course grades and classroom roll calls, free to move from place to place sampling academic wares, presented themselves to the university as mature and self-reliant beings, not as neophytes, tenants or wards' (Metzger 1987, 1270). Hence, this aspect of the Humboldtian model of academic freedom, with its emphasis on the rights of students, had precedents in the University of Bologna model.

The final aspect of academic freedom was the right of academic self-governance and institutional autonomy. Hence 'with substantial state control over appointments, universities were entitled to make their own decisions on internal matters under the direction of the senior faculty. The concept of academic self-governance that undergirds Freiheit der Wissenschaft is recognizable as a forerunner of the emphasis on institutional autonomy that developed in the courts' discussions of academic freedom' (Horwitz 2005, 475). This right was deemed necessary to protect the freedoms of teaching and research. Without such protection, 'the university, it was thought, would be dangerously vulnerable to government or religious censorship. Without broad institutional powers, the academic Gelehrten (staff), it was feared, would be at the mercy of the state or church. ... (hence) institutional autonomy was indispensable to academic freedom’ (Metzger 1987, 1270f).

The unity of teaching and research, (Einheit von Lehre und Forschung) and the collaborative pursuit of these by staff and students was a central aspect of the Humboldtian model. Thus Humboldt considered that universities have 'as their task the cultivation of science and scholarship in the deepest and broadest sense,' in which '[c]ollaboration operates through a process in which the successful intellectual achievements of one person arouse the intellectual passions and enthusiasms 
of others, and through the fact that what was at first expressed only by one individual becomes a common intellectual possession instead of fading away in isolation'. In this process 'both teacher and student have their justification in the common pursuit of knowledge' and hence 'the goals of science and scholarship are worked towards most effectively through the synthesis of the teacher's and the students' dispositions' (Humboldt 1970, 242f). Hence as Lay observes '[t]eaching was to be a means of improving both lecturer and student: true knowledge would emerge in the interplay between experience and enthusiasm’ (Lay 2004, 48).

In sum, the Humboldtian model of academic freedom emphasised the unity between teaching and research, and the consequent need for academic freedom to be enjoyed by both students and university teachers, with the latter possessing professional status as tenured civil servants, allied to institutional autonomy from the state and internal self-governance. Variants of this model are still discernable within European Universities and beyond, and will be familiar to academic staff, who need no convincing of the centrality of the concept to their everyday working lives. However, if such a model is to be adopted within the E.U. Revision Treaty, and moreover to protect its continued existence in individual EU states, it is necessary to convince those outside of academia of the importance of academic freedom: to academics, students, universities as institutions and society at large.

\section{Why is Academic Freedom Important?}

First, academic freedom is clearly important to individual academics. As Shils points out: 'The justification of academic freedom is that it protects the moral and intellectual integrity of the teacher' (Shils 1995, 7). In respect to their teaching, Machlup notes that the situation of academics is unusual as ' $[\mathrm{t}]$ he occupational work of the vast majority of people is largely independent of their thought and speech', while by contrast '[t]he professor's work consists of his thought and speech. If he loses his position for what he writes or says, he will, as a rule, have to leave his profession, and may no longer be able effectively to question and challenge accepted doctrines or effectively to defend challenged doctrines' (Machlup 1955, 756). Therefore, as De George states, academic freedom for teaching 'is the right to teach one's discipline in the way that one, because of his or her knowledge, deems best. If it is for one's knowledge that a university hires a teacher, it must presume that the teacher is the best qualified person it can find to teach the subject' (De George 2003, 17). In this respect Dworkin argues that 'academic freedom insulates scholars from the administrators of their universities ... (who) ... cannot dictate how those who have been appointed will teach what has been decided will be taught' (Dworkin 1996, 183), consequently, 'academic freedom is designed to protect individual scholars, even against the institutions where they serve' (Daughtrey 1990, 270). This protection extends beyond the powers of administrators - as Menand makes clear: 
'Academic freedom not only protects sociology professors from the interference of trustees and public officials in the exercise of their jobs as teachers and scholars; it protects them from physics professors as well' (Menand 1996, 17).

The importance of this right of academic freedom for university teaching was recognized in the USA by the Supreme Court. In 1957, in the case of Sweezy v. New Hampshire, when a university lecturer was held in contempt for refusing to reveal the subject of his lectures, the Court overturned the decision and argued that: 'The essentiality of freedom in the community of American universities is almost self-evident. ... Scholarship cannot flourish in an atmosphere of suspicion and distrust. Teachers and students must always remain free to inquire, to study and to evaluate, to gain new maturity and understanding; otherwise our civilization will stagnate and die. ... History has amply proved the virtue of political activity by minority, dissident groups, who innumerable times have been in the vanguard of democratic thought and whose programs were ultimately accepted. Mere unorthodoxy or dissent from the prevailing mores is not to be condemned. The absence of such voices would be a symptom of grave illness in our society' (Sweezy v. New Hampshire 1957, 250).

Such pronouncements endorse Turner's belief that: 'Academic freedom is ... to the academic profession what judicial independence is to judges, freedom of conscience to the clergy, the protection of sources of information to the journalist, parliamentary privilege to the MP, the exercise of clinical judgement to the doctor, the right of hot pursuit to the policeman' (Turner 1988, 107). Similarly, White sees the concept in its broadest perspective as 'not simply the right of professors to speak without fear or favor, but the atmosphere of consent that surrounded the whole process of research and instruction’ (White 2000, 58). However, as Shils states, limitations do exist - '[an academic] is not free to teach propositions that are contrary to the prevailing tradition unless he can support his contentions with evidence from his own research' (Shils 1991, 4). Additionally, Finkin cautions that academic freedom in teaching carries a reciprocal duty: 'Long professional training, the mastery of the subject matter, and the passage of a period of apprenticeship undergird the assertion of a professional prerogative, in return for which ... the academic is rightly held to a professional standard of care' (Finkin 1987, 1332).

Just as academic freedom is important in protecting the teaching of individual academics, so it is with research. As Thompson relates 'progress toward deeper understanding and new discoveries, in any field, requires a willingness to adopt new perspectives and new approaches. Reaction against change can and does come from any quarter: the state, the church, the business sector, society at large, one's own colleagues' (Thompson 1996, 3). Moreover the protection of academic freedom has become especially important following the growth of external commercially funded research - 
'secrecy of research results, distortion of the viewpoints and claims of academic researchers, and distortion of the research agenda' are, Eisenberg $(1987,1378)$ suggests, 'by no means exhaustive of the ways sponsored research might compromise the integrity of the academic enterprise'. This problem is exacerbated when research productivity is an institutional requirement for promotion or salary enhancement, as Coelho states '[i]n a publish or perish oriented college or university, promotions, tenure, and salary increases are awarded on the basis of an individual's contributions to scholarly journals and his publications of monographs and texts. The more a professor publishes, the more likely he is to be promoted, granted tenure, and given salary increases . . . (and) . . . Academics tend to equate research with productivity' (Coelho 1976, 423). Assessing such claims, Yudof injects some realism into the research justification for academic freedom, by pointing out that studies in the USA reveal that '[o]ne- third of all professors admit to spending no time at all on research, while more than half spend less than five hours a week on it. .. $60 \%$ of a sample of 5000 professors had never published or even edited a book in their subject areas' (Yudof 1987, 842). Shils is similarly critical and argues that '[i]t is frequently said that originality of discovery and analysis is inhibited or suppressed where there is no right of academic freedom, ... I think that this is not straightforward. Most cases of infringement of academic freedom have nothing to do with original thought or discovery. Most academics are not capable of original thought or discovery' (Shils 1995, 7).

However, it is true nevertheless that without the benefit of academic freedom for research, major scientific discoveries, which have irrevocably ameliorated society, would not have been made. Conrad Russell relates the struggles his famous father had in the two years it took him to produce the Principia Mathematica, noting that 'those two years, however much they might appear totally unproductive, were a very valuable investment of academic time. We are now told that the development of the digital computer would have been impossible without the research'. Despite his academic pre-eminence Bertrand Russell was twice removed from his academic post, firstly for his opposition to the First World War, and secondly, his views on marriage, leading his son to remark: 'If this fate can happen twice, to a scholar of this standing, it can happen to lesser men and women also, and the fear of it can inhibit research' (Russell 1993, 24). During the Second World War academic research was responsible for developing the Atomic Bomb, under a team lead by Robert Oppenheimer, while in the UK the mathematician Alan Turing and his colleagues at Bletchley Park devised techniques to break German military cyphers - the work of both these groups (and others) are considered to have been crucial to the war effort. Similarly, in the post-war period, James Watson (1968), in his account of the discovery of the structure of DNA, chronicles how he and Francis Crick (at that time studying for a $\mathrm{PhD}$ in different subject area) were told by Sir Lawrence Bragg (himself a Nobel Laureate) to discontinue their study of DNA. Luckily they continued with 
the work discretely which lead to the discovery of the double helix structure and the award of the Nobel Prize in 1962. Hence even eminent scientists, holders of Nobel prizes and knighthoods, can be mistaken about what research should be pursued, but provided academic freedom exists, university researchers can safely undertake research into areas which their superiors may, erroneously, deem unproductive. James Watson continues to champion academic freedom, in 1990 he stated: 'The nations of the world must see that the human genome belongs to the world's people, as opposed to its nations' (Watson 1990, 48) and consequently resigned as Head of the Human Genome Project, in opposition to the move to acquire patents on gene sequences and any ownership of the 'laws of nature'. Such examples clearly validate Horwitz's claim that '[a]cademic freedom is prized primarily because its contribution to truth-seeking will yield discoveries or insights that ultimately will benefit society at large' (Horwitz 2005, 484).

Despite such case studies and Hamilton's belief that '[m]any academics are extremely independent with a focus on intellectual creativity. They value a secure and stable environment where they can do their work alone' (Hamilton 1996, 558), little empirical work has been undertaken on the impact of academic freedom on research. However, Bennich-Bjorkman's analysis, based on interviews of academic staff in Sweden, discovered that ' $[\mathrm{t}]$ he norm of academic freedom lives on and is significant in the research community even though there are variations in where the emphasis is placed' (Bennich-Bjorkman 2004, 23). More significantly, this study pointed to the important distinction made by Berlin (1969) between negative freedom (the absence of constraint - 'not being prevented from choosing as I do') and positive freedom (the freedom and ability to act and be 'one's own master'). Bennich-Bjorkman found that most of the researchers interviewed had the latter but not the former. Hence researchers were unconstrained in the choices they made for the subject of their research, but were unable to undertake their research through lack of resources. Given the increasing costs of high level research, more especially in the natural sciences like atomic physics, it seems likely that academic freedom for research is moving from positive to negative freedom. For example, in 1671, while Lucasian Professor of Mathematics at Cambridge University, Isaac Newton stated: 'I procured me a triangular glass prism to try therewith the celebrated phenomena of colours' (Newton 1671, 3075). His modern day counterpart, undertaking research into particle cosmology, would require a particle accelerator and collider. As Standler rightly points out: 'What universities and professors really need is not meaningless words about the importance of “academic freedom” from judges, but adequate financial support for professors' salaries, and adequate financial support for scientific equipment and research expenses, libraries, buildings, etc. Academic freedom means nothing if professors can not afford to do the research that they are supposedly free to do' (Standler, 2000). Similarly, Thomson $(1975,257)$ argues that 'it is irrational for a community to support an institution of higher education ... whose 
purposes are the increase and dissemination of knowledge, and at the same time to make it more difficult or impossible for those employed by that institution to increase and disseminate knowledge’.

Evidence exists of the effect that academic freedom has on the performance of academic staff, via differing governance patterns, but it is equivocal. For example, cross sectional empirical work by McCormick and Meiners found that 'autocratically managed universities are more productive than democratically run institutions in terms of publication in journals and the teaching of students' and that 'the results here support the conclusion that faculty successful at research and teaching do not participate much in the actual management of their university, and those who do administer do not publish as much or teach as well' (McCormick and Meiners 1988, 429, 441). Less conclusively, Brown's study found that: 'Greater faculty control over appointment, promotion and tenure decisions and faculty governance decisions is associated with increased performance', while '[g]reater faculty participation in general administration decisions and financial decisions is negatively related to performance,' leading him to conclude that '[t]he observed empirical relationships are not inconsistent with the hypothesis that faculty participation in governance influences performance'. However, he found that the 'overall impact of this participation varies by the types of decisions in which faculty participate', and acknowledged 'the need for better and more comprehensive measures of both university performance and governance' (W. Brown 2001, 130). By contrast Gadd's statistical analysis of the impact of higher education reforms in Sweden, utilising routine bureaucracy, professional expert and collegiate organisational models, found that 'if the extent of self governance in higher education increases, the productivity of higher education also changes in a positive direction' (Gadd 2005, 210). Exemplar case studies provide endorsement for this cross-sectional evidence. For example Max Perutz, Nobel Laureate and founding Director of Cambridge University's Molecular Biology Laboratory, believed that 'creativity in science, as in the arts, cannot be organised. It arises spontaneously from individual talent. Well-run laboratories can foster it, but hierarchical organisation, inflexible, bureaucratic rules, and mountains of futile paperwork can kill it. Discoveries cannot be planned; they pop up, like Puck, in unexpected corners’ (Perutz 2003, ix). Perutz's inspired stewardship, through adherence to these guiding principles, enabled MBL's staff to produce research of the highest quality, subsequently recognised through the award of twelve Nobel prizes since 1962. Similarly, writing in the Oxford Magazine in 1997, the Warden of Nuffield College, Nevil Johnson, counselled his colleagues that '[a] university managed like an industrial enterprise is an impossibility: it would just no longer be a university. ... We cannot “manage” people into successful teaching, nor can we ensure by good management that people do high quality research or write original books’ (Johnson 1997, 4). 
Adopting a case study approach to involvement by academic staff in governance within four institutions, Hamilton concluded that 'academic tradition ties the shared governance tradition directly to peer review, academic freedom and the mission of the university to create knowledge and teach critical inquiry' (Hamilton 2004, 98). Similarly, Shattock’s review of U.K. institutional case studies (including Cambridge) led him to conclude that ' $[\mathrm{t}]$ here are some universities, probably mostly the most academically successful, which have developed a strong organizational culture that effectively marries academic and managerial structures to provide both effective decision-making machinery and a strongly self motivated academic community. Such a structure is likely to be able to resist the worst aspects of ... managerialism and to be able to preserve a robust academic ethos' (Shattock 1999, 281). Furthermore he found 'little hard evidence that the new managerialism ... has been particularly successful in delivering academic success' and that 'where improprieties and breakdowns have occurred, they have centred on governing bodies and the executive and not on the academic community. Indeed, in nearly all such cases ... attention was drawn to the difficulties by concern in the academic community' (Shattock 2002, 240). This conclusion is endorsed by Brown's survey of governance in U.K. universities which found that '[i]f there is one common feature running through these reports it is the difficulty which these institutions had in controlling the behaviour of a strong chief executive who was often closely associated with a small group of key Governors who may have bypassed a largely supine Governing Body, many of whom were not sufficiently knowledgeable either about higher education matters or about their own rights and responsibilities as members of the supreme decision making body of a higher education institution' (R. Brown 2001, 44). In sum, these findings demonstrate that when the intellectual curiosity inherent in academic freedom is sacrificed for the institutional conformity required by administrative functionaries, academic mediocrity, rather than merit, is the more likely outcome.

There is no discernable data on the impact of participation in the appointment of the Rector (or the equivalent chief managerial officer within the university - Vice Chancellor, University President, etc.) on academic freedom. However, where the Rector is an external appointment for an indefinite term by an external agency, s/he will be in a position to abuse academic freedom, more especially where the staff lack the protection of tenure. By contrast, a Rector chosen internally by the academic staff, for a limited period, is unlikely to undermine the staff's academic freedom, as such actions will lead to retaliatory actions and removal from office. Moreover, an internal nominee who knows well the strengths, weaknesses and internal organisation of the institution, can act decisively, knowing s/he already possesses the support and trust of the university staff. Giving the powers of appointment to the staff, and thereby making them responsible for their decisions, enables them to make informed and inspired choices, secure in the knowledge that their appointment, if ill-chosen, can be easily removed from office and safely returned to work in his/her 
Department. By contrast, an appointment board dominated by nominees from outside higher education and less well-informed about the needs of university than are the academic staff, is more likely to make ill-informed and inappropriate appointments, or to be more risk averse and therefore unlikely to make innovative appointments. Significantly, a cross sectional analysis by Goodall of the top 100 universities, as identified by Shanghai Jiao Tong University's Institute of Higher Education, examined the research credentials (articles and citations in top ranked journals, Nobel prizes, etc.) of their executive leaders (Vice-Chancellors, Rectors, etc.). The study revealed that '[t]he most highly ranked universities have leaders who are more highly cited', and that '[i]nternationally active researchers lead the world's top universities. On average the higher the university is in the global ranking, the more highly cited is that institution's president' (Goodall 2006, 397, 402). Presidents who are pre-eminent in their research fields are more likely to understand the need to protect academic freedom in the institutions that they lead, than are their counterparts who are drawn from outside of academia, or who have been appointed on the basis of non-research expertise. Such findings provide empirical reinforcement for the view that academic freedom has a positive impact on research productivity and university excellence.

As well as being crucial to academic staff in the successful fulfilment of their professional roles, academic freedom for students has been, and remains, important. In the $12^{\text {th }}$ century, as Lay relates, students at Bologna demanded 'the right to appoint their own lecturers, and to direct the curriculum they would be taught' (Lay 2004, 32), and within the later Humboldtian university model 'to the university student, Lernfreiheit, was a precious privilege, a recognition of his arrival at man's estate' (Hofstadter and Metzger 1955, 387). Hence, as Barnett observes, under the idealist epistemology adopted by Humboldt and the founders of the modern German university 'knowledge . . . was to be gained through entering a critical dialogue with others. Consequently, there was no difference in kind in the formal position of teachers and taught. Both were engaged in the same kind of activity, in exploring accounts of the world through participation in a conversation. ... (thus) ... it was entirely apposite for the notion of student freedom to arise' (Barnett 1990, 138). Interestingly, Moens notes that under this concept '[s]tudents were free to move from one place to another to sample academic offerings ... (and) ... this understanding of a student's right to academic freedom enjoys a revival in the European Community where students are encouraged to seek part of their education in a Member State of which they are not nationals’ (Moens 1991, 59). However, as Tight points out '[i]t is not sufficient to rely solely on the historical notion of Lernfreiheit in considering what elements of academic freedom students may have a need for or an entitlement to' (Tight 1988, 121), supporting Magsino's view that ‘the claim to student academic freedom has not been presented with either clarity, consistency or adequacy’ (Magsino 1978, 48). 
In partial answer to this, Derrington's judicial opinion is that in contemporary universities 'academic freedom of students consists not only of the right to dissent without penalty, but also, of a freedom from oppression, by the lecturer's peddling of his own idiosyncratic views in a way that would unduly influence their vulnerable minds; and a freedom from having a fair representation of opposing views withheld from them' (Derrington 1991, 92f). In the USA, the Supreme Court provided legal support for this view in the Keyishian v. Board of Regents judgment in 1967 when it declared that: 'Our Nation is deeply committed to safeguarding academic freedom, which is of transcendent value to all of us, and not merely to the teachers concerned. The classroom is peculiarly the "marketplace of ideas.” The Nation's future depends upon leaders trained through wide exposure to that robust exchange of ideas which discovers truth "out of a multitude of tongues, [rather] than through any kind of authoritative selection"' (Keyishian v. Board of Regents 1967, 603). Implicit in the notion of the classroom as a 'marketplace of ideas' is the Humboldtian ideal of scholarship as the shared common pursuit of knowledge, and thereby the necessary requirement of academic freedom for staff and students alike. Hence Monypenny $(1963,633)$ argues that 'educational institutions ... must be a community in which ideas can develop, be exchanged, tested, and discarded, in which the unorthodox is given a hearing and in which the inhibitions against the new and the strange are at a minimum. Such a community cannot be a community of teachers only, since the most important product of teachers is their students. Their students can have the advantage of the characteristic experience of the community, of free intellectual innovation and exchange, only by participating in it.'

The claim of students to such rights was strengthened in 1995 by the Supreme Court in the case of Rosenberger v. Rector and Visitors of the University of Virginia which made direct reference to the academic freedom's genesis within the universities of Europe. Justice Kennedy, addressing the perceived danger to individual thought and expression, argued that '[the] danger is especially real in the University setting, where the State acts against a background and tradition of thought and experiment that is at the center of our intellectual and philosophic tradition. . . In ancient Athens, and, as Europe entered into a new period of intellectual awakening, in places like Bologna, Oxford, and Paris, universities began as voluntary and spontaneous assemblages or concourses for students to speak and to write and to learn. ... The quality and creative power of student intellectual life to this day remain a vital measure of a school's influence and attainment. For the University, by regulation, to cast disapproval on particular viewpoints of its students risks the suppression of free speech and creative inquiry in one of the vital centers for the nation's intellectual life, its college and university campuses’ (Rosenberger v. Rector 1995, 819). 
The freedom of academic staff to protect the academic credibility and content of courses is important to students who thereby 'benefit from the academic freedom of the faculty and perhaps from the atmosphere of freedom which should prevail on a campus' (van den Haag 1963, 515), while '[a]cademics who cherish academic freedom for themselves and deliberately, or even knowingly, deprive their students of it, by acting contrary to these principles, are intellectually dishonest' (Derrington 1991, 93). As Standler (2000) points out, if the syllabus and teaching methods are less challenging at one university, than at others, then a degree from that university is worth less than a degree from a university with higher academic standards. If university students wish to remain competitive in an increasingly international job market, their best interests are served by ensuring that there are uniformly high standards in university education. Confirming this, Åkerlind and Kayrooz reported that '[p]reliminary findings also suggest that constraints on academic freedom may be a factor in falling teaching and student standards and an emphasis on “safe” rather than speculative or contentious research’ (Åkerlind and Kayrooz 2003, 327). With respect to these findings that constraints on academic freedom may lead to falling teaching standards, it is worth noting that the U.K. h.e. sector, in which, as Karran (2007) demonstrated, academic freedom has less legal protection than other E.U. nations, found it necessary in the 1990's to establish a national quality assurance agency for higher education to undertake institutional and subject audits to ensure that teaching quality was being maintained

In addition to being important to staff and students, academic freedom is a defining character of the health of universities. Hence Manan declaims that '[a]cademic freedom is a pre-condition for academic excellence' (Manan 2000, 255), while Abdel-Motaal believes that '[t]he fundamental purpose of Academic Freedom - and it is all too often forgotten - is to instill and to maintain those conditions within the university that are conducive to fostering and advancing creativity, social development and to sustaining the advancement of knowledge' (Abdel-Motaal 2002, 369). In a like vein, Altbach (2001, 205f) states that: '[a]cademic Freedom is at the very core of the mission of the university. It is essential to teaching and research. . . for without academic freedom, universities cannot achieve their potential nor fully contribute to the emerging knowledge-based society'. Furthermore, Human Rights Watch has argued that '[a] university fulfils its mission when academics are not forced to support an official line, an economic agenda, or a political ideology, but rather are free to use their talents to advance human knowledge and understanding' (Human Rights Watch), while Byrne states '[a]cademic freedom provides both functional and aspirational norms for the university. . . . Academic freedom always remains enmeshed in the changing fortunes of higher education in the larger society, yet its meaning cannot be exhausted in contingency and pragmatism. It maintains our connection with an ideal academy where disinterested scholars pursue living knowledge with rigor and grace’ (Byrne 1993, 317). 
Perhaps the strongest justifications for academic freedom as an essential pre-requisite for institutional excellence have come from past Presidents of Harvard and Yale, universities rightly deemed paragons of research pre-eminence and scholarly endeavour. Kingman Brewster, President of Yale for over a decade (and later Master of University College, Oxford) asserted that '[i]n strong universities, assuring freedom from intellectual conformity coerced within the institution is even more of a concern than is the protection of freedom from external interference . . This spirit of academic freedom within the university has a value which goes beyond protecting the individual's broad scope of thought and inquiry. . . . If a university is alive and productive, it is a place where colleagues are in constant dispute; defending their latest intellectual enthusiasm, attacking the contrary views of others. . . . It is vital that this contest be uninhibited by fear of reprisal. . . The more subtle condition of academic freedom is that faculty members, once they have proved their potential during a period of junior probation, should not feel beholden to anyone, especially Department Chairmen, Deans, Provosts or Presidents, for favour, let alone for survival' (Brewster 1972, 328). Echoing this view, Derek Bok, President of Harvard for over 20 years, has written 'academic freedom is not merely a reflection of society's commitment to free speech; it is a safeguard essential to the aims of the university and to the welfare of those who work within it. Teachers and scholars have a vital stake in continuing to enjoy the liberty to speak and write as they choose, because their lives are entirely devoted to developing and expounding ideas. Universities in turn have a critical interest in preserving free expression, for without that freedom they will be hampered in appointing the most creative scientists and scholars and will suffer from forms of censorship that will jeopardise the search for knowledge and new discovery that represents their most distinctive contribution’ (Bok 1982, 20).

At societal level, academic freedom is indicative of democratic values within the wider community, as many scholars have noted. Hughes, for example, argues that ' $\mathrm{t}$ ]he rationales underlying the guarantee of freedom of expression in society at large are equally applicable to the university setting. Freedom of expression is necessary both for democratic government and the determination of what matters in the university’ (Hughes 1995, 79). Consequently Rochford, finds that 'academic freedom is not for the benefit of the academic, or even of the institution. It is for the benefit of society at large, and society's failure to provide the environment in which this freedom can flourish will result in the loss of a valuable asset' (Rochford 2003, 259). A similar argument is advanced by Lynch, who states that 'where the state's goals are critical democratic education or the promotion of new discoveries, academic freedom is not a hindrance but rather is crucial to the accomplishment of the state’s mission’ (Lynch 2003, 1063). More strongly, Bergan considers academic freedom to be 'the heart of democratic society . . . a democratic society is hardly conceivable without . . . academic freedom’ (Bergan 2002, 49), a sentiment echoed by van Ginkel’s 
belief that '[a]cademic freedom is a practical exercise in learning and advancing democracy' (van Ginkel 2002, 351). Hence, Manan postulates, '[i]n a society that has a high regard for knowledge and universal values, the scope of academic freedom is wide. On the other hand, in authoritarian and autocratic societies, the scope for academic freedom is very narrow' (Manan 2000, 257). Similarly Tuner argues that 'academic freedom stands as one of the freedoms which a free society should value, cherish and maintain. A society which erodes or abolishes it is destroying a part of its civilized values, and may go on to destroy the others. It has been wisely said that the first target of those who wish to set up dictatorships is freedom of speech, the freedom of academics included' (Turner 1988, 111). Pritchard agrees that 'academic freedom is but a facet of freedom in the larger society and malaise in academe is related to, and symptomatic of, that in the body politic as a whole' and relates that 'academic freedoms are implicit rather than explicit in the United Kingdom ... The erosion of these freedoms in academe is merely a reflection of a constitutional crisis in the larger society’ (Pritchard 1998, 123).

An allied argument is advanced by Allen $(1988,112)$ who suggests that 'one of the services which universities can render is to provide serious and direct criticism of the society of which they are a part'. Moreover, as Burgess points out, this role is significant even in democracies, for '[d]emocratic governments can err. Popular demand may be foolish. Both can be arbitrary, unjust and capricious. A democratic society is a plural society, one in which criticism is welcome and alternatives possible. ... Many of the greatest advances have been made against political oppression, popular indifference or worse' (Burgess, 1979, 145). Consequently, as Hernes contends, 'Professors have not just served as experts and attendants for the powerful which fed them. They have represented counter-expertise. Hence politicians and the powers that be have not always seen professors as easy to handle - or believed that their knowledge produces wisdom' (Hernes 1993, 270). Sjoberg (1998) carries this argument further by suggesting that academic freedom is also important in enabling university staff to criticise and hold private corporations to account for their actions. Hence academic freedom enables university staff to provide expert criticism of the workings of government and the corporate sector, and ensure that they are accountable for their actions, thereby strengthening democracy. In this sense, as Machlup observed, 'academic freedom is a right of the people, not a privilege of a few' (Machlup 1955, 753).

\section{Conclusion}

Writing in 1993, Edward Shils posed the question: 'Do We Still Need Academic Freedom?' Directing his question at academia, rather than broader society, Shils concluded there was an acknowledgement that 'substantive academic freedom was now so well established that the academic profession ... could cease to be anxious about its protection' (Shils 1993, 209). However, 
for academic freedom to flourish requires a consensus from within academia and the world at large that retention of the concept is beneficial to all, and not just university staff and students. Hence, this paper's purpose was to critically examine the justification for, and benefits of, academic freedom, to both the academic community and society in general. Over 40 years ago the Robbins Committee on Higher Education in the U.K. concluded that academic freedom 'is a necessary condition of the highest efficiency and the proper progress of academic institutions and that encroachments upon their liberty, in the supposed interests of greater efficiency ,would in fact diminish their efficiency and stultify their development' (Robbins 1963, 229). The arguments advanced in this paper confirm this conclusion and demonstrate that academic freedom is important to everyone's well-being, as well as being particularly pertinent to academics and their students, in their daily activities of teaching and learning. Moreover, it is likely that the beneficial impacts of academic freedom will increase rather than decrease in the future, for the following reasons.

Firstly, society is moving towards a knowledge economy and pushing back the frontiers of knowledge secures economic growth and prosperity - estimates have shown that the growth in the volume of knowledge is accelerating, and can now double every five years (van Ginkel 1994, 72). To operate successfully within such an environment, Botkin et al. (1979) believe, requires a shift from maintenance learning (i.e. acquiring an historical body of knowledge required to deal with known recurring events and problems) to dynamic learning (which encourages problem reformulation and novel thinking to facilitate knowledge creation). Such learning is best encouraged within an academic environment that stresses and encourages critical debate of the status quo, with an atmosphere of wide freedom of expression.

Secondly, the growth of knowledge and the increasing use of information technologies is making civil society increasingly complex, making it more difficult, yet more important, to hold government and its agencies to account for their actions. Events in the last decade, and e especially since the terrorist attacks on the USA in September 2001, have led to the questioning of government policy, by the public at large and academics (attempting to understand why such attacks took place), being denounced as unpatriotic, with the result that ' $[t]$ he free expression of ideas means something entirely different at the start of the 21st century than it did only a decade ago' (Tierney and Lechuga 2005, 13). For example, Cooper relates that '[c]riticisms of the professoriate monopolized much of the post-September 11 conversations regarding higher education and academic freedom' (Cooper 2003, 77), while Strauss' case study demonstrates how 'the disruption and public outcry (were) cited to negate so-called “academic freedom” and to censure a Professor's right to free expression' (Strauss 2004, 345f). For democracy to thrive within an open and tolerant society, academic freedom needs to be protected, to ensure that students can be encouraged, by example and 
instruction, into independent thinking and critical reasoning, and thereby better fulfill their responsibilities as active, participative citizens within an increasingly global community. As Robert Hutchins, the educational philosopher and President and Chancellor of Chicago University observed: 'The object of the educational system, taken as a whole, is not to produce hands for industry or to teach the young how to make a living. It is to produce responsible citizens' (Hutchins 1953, 3).

Historical analyses reveal that academic freedom was hard won within the early universities of Europe, with some academics (like Giordano Bruno) paying for their beliefs with their lives, while others moved to different cities (for example, from Paris to Oxford) and countries to escape persecution and continue with their research and teaching without censure or constraint. The disinclination for contemporary academics to protect their academic freedom with similar vigour is disheartening. For example, surveying the abolition of the right of employment tenure for academics in 1988 in the U.K.'s universities, Halsey noted that although 'the demand from the state that intellectual labour be proletarianised, has been conspicuously aggressive in the past decade. The counter-attack has been surprisingly mild', which he attributed to 'another value nurtured in higher education - the tolerance of hostile ideology and the patience to pursue reasoned argument' (Halsey 1992, 270). Such a reasoned and reasonable stance is appropriate and effective in a society in which factual debate and logical enquiry inform both public opinion and government policy, but is neither credible nor effective in current circumstances when (as, for example, in the United States) half the adult population disavow Darwin's writings and believe in creationism (Miller et al. 2006, 756), or overwhelmingly maintain that Saddam Hussein was personally involved in the 9/11 attacks (Millbank and Deane 2003).

During the inter-war Great Depression, responding to press accusations of communist infiltration of the academic staff at Chicago University, the President, Robert Hutchins, retorted: 'The answer to such charges against a university is not denial, nor evasion, nor apology. It is the assertion that free inquiry is indispensable to the good life, that universities exist for the sake of such inquiry, that without it they cease to be universities, and that such inquiry and hence universities are more necessary now than ever. The sacred trust of the universities is to carry the torch of freedom' (Boyer 2002, 6). In addition to his Presidential duties, Hutchins was the Editor of the Great Books of the Western World series. The author of one of the 'great books', the 18thcentury historian Edward Gibbon (1952, 596) attributed the decline and fall of the Roman Empire to (amongst others) the following factor: 'The freedom of the mind, the source of every generous and rational sentiment, was destroyed by the habits of credulity and submission'. Such words should rightfully caution university scholars that continued pavidity and reliance on reasoned argument 
will do little to curtail or reverse the attacks on, and dilution of, academic freedom. The philosopher and Nobel Peace Laureate Albert Schweitzer $(1975,51)$ observed that: 'Example is not the main thing influencing others. It is the only thing'. Following on from Shils' question, it is worth asking: If we, as academics, allow our freedoms to be eroded so readily, what example are we passing on to those we teach? 


\section{References}

Abdel-Motaal, Mostafa B. 2002. Academic Freedom and Civil Society: Some Personal Reflections. Higher Education Policy 15: 365-70.

Åkerlind, Gerlese S. and Carole Kayrooz. 2003. Understanding academic freedom: the views of social scientists. Higher Research and Development 22: 327-44.

Allen, Michael, 1988. The Goals of Universities, Buckingham: SRHE/Open University Press.

Altbach, Philip. 2001. Academic freedom: International realities and challenges. Higher Education 41: 205-19.

Anderson, Robert. 2000. Before and after Humboldt: European universities between the eighteenth and the nineteenth centuries. History of Higher Education Annual 20: 5-14.

Barnett, Ronald. 1990. The Idea of Higher Education, Buckingham: SRHE/Open University Press.

Bennich-Björkman, Li. 2004. Has Academic Freedom Survived? Stockholm: National Agency for Higher Education.

Bergan, Sjur. 2002. Institutional Autonomy between Myth and Responsibility. In Autonomy and Responsibility: The University's Obligations for the XX1 Century - Proceedings of the Launch Event for the Magna Charta Observatory. 49-66. Bologna: Bononia University Press.

Berlin, Isaiah. 1969. Two Concepts of Liberty. In Four Essays on Liberty. Oxford: Oxford University Press.

Bok, Derek. 1982. Beyond the Ivory Tower: Social Responsibilities of the Modern Universities. Cambridge: Harvard University Press.

Botkin, James, Mahdi Elmandjra, and Mircea Malitza. 1979. Bridging the Human Gap. Oxford: Pergamon Press.

Boyer, John W. 2002. Academic Freedom and the Modern University: The Experience of the University of Chicago. The University Of Chicago Record 37: 2-25.

Brewster, Kingman. 1972. On Tenure. Academe 58: 381-83.

Brown, Roger. 2001. The Governance of the New Universities: do we need to think again? Perspectives 5: 42-7.

Brown, William O. 2001. Faculty Participation in University Governance and the Effects on University Performance. Journal of Economic Behavior \& Organization 44: 129-43.

Bruch, Rüdiger vom. 1997. A Slow Farewell to Humboldt? Stages in the History of German Universities 1810-1945. In German Universities Past and Future: Crisis or Renewal?, ed. Mitchell G. Ash, 3-27. Providence and Oxford: Berghahn Books.

Burgess, Tyrell. 1979. New Ways To Learn. Journal of the Royal Society of Arts 128: 143-55. 
Byrne, Peter. 1993. Academic Freedom and Political Neutrality in Law Schools: An Essay on Structure and Ideology in Professional Education. Journal of Legal Education 43: 315-39.

Coelho, Philip R. P. 1976. Rules, Authorities, and the Design of Not-for-Profit Firms. Journal of Economic Issues 10: 416-28.

Connolly, John M. 2000. The Academy's Freedom, The Academy's Burden. Thought \& Action 16: 69-82.

Cooper, Michelle Asha. 2003. Academic Freedom in the 21st Century. Thought \& Action 20: 7585.

Daughtrey, Willian H. 1990. The Legal Nature Of Academic Freedom In United States Colleges And Universities. University Of Richmond Law Review 25: 233-71.

De George, Richard T. 2003. Ethics, academic freedom and academic tenure. Journal of Academic Ethics 1: 11-25.

Derrington, Mr Justice. 1991. Academic Freedom: A Judicial View. Bulletin of the Australian Society of Legal Philosophy 16: 91-4.

Dodds, Harold W. 1963. Academic Freedom And The Academic President. Law \& Contemporary Problems 28: 602-6.

Dworkin, Ronald. 1996. We Need a New Interpretation of Academic Freedom. In The Future of Academic Freedom, ed. Louis Menand, 181-98. Chicago: University of Chicago Press.

Eisenberg, Rebecca S. 1987. Academic Freedom and Academic Values in Sponsored Research. Texas Law Review 66: 1363-404.

European Union. 2007. Revision Treaty Of The European Union. Luxembourg: Office for Official Publications of the European Communities.

European Universities Association. 1988. Magna Charta Universitatum. Bologna: EUA.

Finkin, Matthew W. 1987. Intramural Speech, Academic Freedom, and the First Amendment. Texas Law Review 66: 1323-49.

Flexner, Abraham. 1930. Universities: English, German. New York: Oxford University Press.

Gadd, Håkan. 2005. Autonomi och Effektivitet I det Svenska Hogskolesystemet. PhD. diss., Abo Akedemi.

Gerber, Larry G. 2001. 'Inextricably Linked': Shared Governance and Academic Freedom. Academe 87: 22-4.

Gibbon, Edward. 1952. The History of the Decline and Fall of the Roman Empire. Vol. 40 and 41 of Great Books of the Western World, eds. Robert M. Hutchings and Mortimer J. Adler. Chicago: Encyclopaedia Britannica Inc. 
Ginkel, Hans van. 1995. University 2050: The Organisation of Creativity and Innovation. In Universities in the 21st Century: A Lecture Series, ed. John Raisman, 65-86. London: National Commission on Education.

—. 2002. Academic freedom and social responsibility - the role of university organisations. Higher Education Policy 15: 347-51.

Goldstein, Stephen R. 1976. The Asserted Constitutional Right of Public School Teachers to Determine What They Teach. University of Pennsylvania Law Review 124: 1293-357.

Goodall, Amanda H. 2006. Should Top Universities be Led by Top Researchers and Are They? Journal of Documentation 62: 388-411.

Haag, Ernest van den. 1963. Academic Freedom in the United States. Law \& Contemporary Problems 28: 515-24.

Haddon, Phoebe A. 1987. Academic Freedom and Governance: A Call for Increased Dialogue and Diversity. Texas Law Review 66: 1561-75.

Halsey, A. H. 1992. Decline of Donnish Dominion: The British Academic Professions in the Twentieth Century. New York: Oxford University Press.

Hamilton, Neil W. 1996. Buttressing the Neglected Traditions of Academic Freedom. William Mitchell Law Review 22: 549-71.

- 2004. Faculty Involvement in System-wide Governance. In Competing Conceptions of Academic Governance, ed. William G. Tierney, 77-103. Baltimore: Johns Hopkins University Press.

Hernes, Gurmund. 1993. Images of Institutions of Higher Education. Higher Education Management 5: 265-71.

Hillier, J. K. 1989. Book Review. The Canadian Historical Review 70: 117-8.

Hofstadter, Richard. and Walter P. Metzger. 1955. The Development Of Academic Freedom In The United States. New York: Columbia University Press.

Horwitz, Paul. 2005. Grutter's First Amendment. Boston College Law Review 46: 461-590.

Howard, Thomas Albert. 2006. Protestant Theology and the Making of the Modern German University. New York: Oxford University Press.

Humboldt, Wilhelm von. 1970. On the Spirit and Organisational Framework of Intellectual Institutions in Berlin. Translated by Edward Shills, Minerva 8: 242-50. Originally published as Humboldt, Wilhelm von. 1903. Uber die innere und äussere Organisation der höheren wissenschaftlichen Anstalten in Berlin. In Gesammelte Schriften, Bd. 10: 250-60. Berlin: B. Behr's Verlag

Hughes, Patricia. 1995. Reconciling Valuable Interests; Or Academic Freedom as Academic Responsibility. University of New Brunswick Law Journal 44: 79-86. 
Human Rights Watch. Http://www.hrw.org/advocacy/academic/afp5.htm.

Hutchins, Robert. 1953. The University of Utopia. Chicago: The University of Chicago Press.

Johnson, Nevil. 1997. Universities: What is there to Manage? Oxford Magazine, 139 (4 ${ }^{\text {th }}$ Week Hilary Term): 4-5.

Jones, H. S. 2007. Intellect and Character in Victorian England: Mark Pattison and the Invention of the Don. Cambridge: Cambridge University Press.

Karran, Terence. 2007. Academic Freedom in Europe: A Preliminary Comparative Analysis. Higher Education Policy 20: 289-313.

Keyishian v. Board of Regents of the State Univ. of New York. 385 U.S. 589603 (1967).

Lay, Stephen. 2004. The Interpretation of the Magna Charta Universitatum and its Principles. Bologna: Bononia University Press.

Lenhardt, Gero. 2002. Europe and Higher Education between Universalisation and Materialist Particularism. European Educational Research Journal 1: 274-89.

Lynch, Rebecca Gose. 2003. Pawns of the State or Priests of Democracy? Analysing Professors’ Academic Freedom Rights Within the State’s Managerial Realm. California Law Review 91: 1061-108.

Machlup, Fritz. 1955. Some Misconceptions Concerning Academic Freedom. AAUP Bulletin 41: 753-84.

Magsino, Romulo F. 1978. Student Academic Freedom and the Changing Student/University Relationship. In Ethics and Educational Policy, eds. Kenneth A. Strike and Kieran Egan, 36-57. London: Routledge and Kegan Paul.

Manan, Wan. 2000. Academic Freedom: Ethical Implications and Civic Responsibilities. In The Universities’ Responsibilities to Society: International Perspectives, ed. Guy Neave, 253-70. Kidlington: Elsevier Science.

McCormick, Robert, and Roger Meiners. 1988. University Governance: A Property Rights Perspective. Journal of Law and Economics 31: 423-42.

McGuinness, Kevin. 2002. The Concept of Academic Freedom. New York: Edwin Mellen Press.

Menand, Louis. 1996. The Limits of Academic Freedom. In The Future of Academic Freedom, ed. Louis Menand, 1-20. Chicago: University of Chicago Press, pp. 1-20.

Metzger, Walter. 1973. Academic Tenure in America: A Historical Essay. In Faculty Tenure: A Report and Recommendations, eds. William R. Keast and John W. Macy, 93-159. San Francisco: Jossey-Bass Inc.

. 1987. Profession and Constitution: Two Definitions of Academic Freedom in America. Texas Law Review 66: 1265-322. 
Milbank, Dana and Claudia Deane. Hussein Link to 9/11 Lingers in Many Minds. Washington Post, September 6, 2003, A01.

Miller, Jon D., Eugenie C. Scott and Shinji Okamoto. 2006. Public Acceptance of Evolution. Science 313: 765-6.

Miyasaka, Masahide. 2005. The Recent Trends of Historical Research on the Founding of Berlin University and Humboldt's Idea of a University. In The Idea of a University in Historical Perspective: Germany, Britain, USA, and Japan, Reviews in Higher Education No. 84, eds. Katsuya Senba,Yoshihito Yasuhara,and Takashi Hata, 1-10. Higashi-Hiroshima, Japan: Research Institute for Higher Education, Hiroshima University.

Moens, Gabriel. 1991. Academic Freedom: An Eroded Concept. Bulletin of the Australian Society of Legal Philosophy 16: 57-70.

Monypenny, Philip. 1963. Toward A Standard for Student Academic Freedom. Law \& Contemporary Problems 28: 625-35.

Moodie, Graeme C. 1996. On Justifying the Different Claims to Academic Freedom. Minerva 34: 129-50.

Neave, Guy. 1988. On Being Economical with University Autonomy: Being an Account of the Retrospective Joys of a Written Constitution. In Academic Freedom and Responsibility, ed. Malcolm Tight, 31-48. Buckingham: SRHE/Open University Press.

Newton, Isacc. 1671. Letter sent to Secretary of the Royal Society, $6^{\text {th }}$ February 1671 . Philosophical Transactions of the Royal Society, 6: 3075-87

Nybom, Thorsten. 2003. The Humboldt Legacy: Reflections on the Past, Present, and Future of the European University. Higher Education Policy 16: 141-59.

Paletschek, Sylvia. 2001. Verbreitete sich ein "Humboldtsches Modell" an den deutschen Universitäten im 19. Jahrhundert? In Humboldt International: Der Export des deutschen Universitätsmodells im 19. und 20. Jahrhundert, ed. Rainer Christoph Schwinges, 75-104. Basel: Schwabe\& Co.

Perutz, Max. 2003. I Wish I had Made you Angry Earlier: Essays on Science, Scientists and Humanity. Cold Spring Harbour, NY: Cold Spring Harbour Laboratory Press.

Polanyi, Michael. 1947. The Foundations of Academic Freedom. Oxford: Society for Freedom in Science.

Preece, A. Alun. 1991. Academic Freedom and Freedom of Speech. Bulletin of the Australian Society of Legal Philosophy 16: 32-56.

Pritchard, Rosalind M. O. 1998. Academic freedom and Autonomy in the United Kingdom and Germany. Minerva 36: 101-24. 
Rabban, David. 1987. Does Academic Freedom Limit Faculty Autonomy? Texas Law Review 66: 1405-30.

Robbin, Lionel. 1963. Higher Education Report of the Committee appointed by the Prime Minister under the Chairmanship of Lord Robbins 1961-1963, (Cmnd. 2154). London: HMSO.

Rochford, Francine. 2003. Academic freedom as insubordination: the legalisation of the academy. Education and the Law 15: 249-62.

Rosenberger v. Rector and Visitors of the University of Virginia. 515 U.S. 819 (1995).

Russell, Conrad. 1993. Academic Freedom. London: Routledge.

Schaff, Philip. 1857. Germany; its Universities, Theology, and Religion. Philadelphia: Lindsay and Blakiston.

Schweitzer, Albert. 1975. Thoughts for Our Times. Ed. Erica Anderson. Mount Vernon, N.Y.: Peter Pauper Press.

Shattock, Michael. 1999. Governance and Management in Universities: The Way We Live Now. Journal of Education Policy 14: 271-82.

2002. Re-Balancing Modern Concepts of University Governance. Higher Education Quarterly 56: 235-44.

Shils, Edward. 1991. Academic Freedom. In International Higher Education: An Encyclopedia, Vol.1, ed. Philip Altbach, 1-22. New York and London: Garland Publishing.

—. 1993. Do We Still Need Academic Freedom? The American Scholar 62: 187-209.

—. 1995. Academic Freedom and Permanent Tenure. Minerva 33: 5-17.

Sjoberg, Gideon. 1998. Democracy, Science and Institutionalized Dissent: Toward a Social Justification for Academic Tenure. Sociological Perspectives 41: 697-721.

Standler, Ronald B. 2000. Academic Freedom in the USA, http://rbs2.com/afree.htm.

Stewart, M. Alexander. 1991. Academic freedom: Origins of an Idea. Bulletin of the Australian society of Legal Philosophy 16: 1-31.

Strauss, Jeffrey S. 2004. Dangerous Thoughts? Academic Freedom, Free Speech, and Censorship Revisited in a Post-September 11th America. Washington University Journal Of Law And Policy 15: 343-68.

Súilleabháin, Gearóid Ó. 2004. Ziff Papiere 125: The Convergence of Traditional Higher Education and E-Learning: Organisational, Societal, Technological and Pedagogical Trends. Hagen: Zentrales Institut für Fernstudienforschung.

Sweezy v. New Hampshire. 354 U.S. 234 (1957).

Thompson, Jon. 1996. Academic Freedom. Paper presented at the Atlantic Association of Registrars and Admissions Officers Interchange’96 Conference, University of New Brunswick at Saint John. 
Thomson, Judith Jarvis. 1975. Academic Freedom and Research. In The Concept of Academic Freedom, ed. Edmund Pincoffs, 255-62. Austin and London: University of Texas Press.

Thorens, Justin. 2006. Liberties, Freedom and Autonomy: A Few Reflections on Academia's Estate. Higher Education Policy 19: 87-110.

Tierney, William G., and Vicente M. Lechuga. 2005. Academic Freedom in the 21st Century. Thought \& Action 21: 7-22.

Tight, Malcolm. 1988. So What is Academic Freedom? In Academic Freedom and Responsibility, ed. Malcolm Tight, 114-32. Buckingham: SRHE/Open University Press.

Traver, A. G. 1997. Rewriting History? The Parisian Secular Masters’ Apologia of 1254. In History of Universities: Volume XV, ed. Peter Denley, 9-45. Oxford: Oxford University Press.

Turner, John. 1988. The Price of Freedom. In Academic Freedom and Responsibility, ed. Malcolm Tight, 104-13. Buckingham: SRHE/Open University Press

Watson, James. 1968. The Double Helix. London: Weidenfeld and Nicolson.

—. 1990. The Human Genome Project: Past, Present, and Future. Science 248: 44-9.

Weidner, Donald J. 2001. Thoughts on Academic Freedom: Urofsky and Beyond. University of Toledo Law Review 33: 257-68.

White, Lawrence. 2000. Academic Tenure: Its Historical And Legal Meanings In The United States And Its Relationship To The Compensation Of Medical School Faculty Members. Saint Louis University Law Journal 44: 51-80.

Yudof, Mark G. 1987. Three Faces of Academic Freedom. Loyola Law Review 32: 831-58. 